\title{
Dreamers: Living Undocumented in Contemporary Young Adult Fiction
}

\begin{abstract}
Amy Cummins ${ }^{1}$
This article analyzes characteristics of living with undocumented legal status in the United States and examines how the young adult novels The Secret Side of Empty (2014) by Maria E. Andreu, Illegal (2011) by Bettina Restrepo, and Sanctuary Somewhere (2019) by Brenna Dimmig depict significant aspects of unauthorized residents, such as resilience, vulnerability, educational striving, family relationships, disclosure, financial and occupational limits, and uncertain futures. Critical content analysis of the books' narrative elements and writing styles leads to evaluation of the literary texts. The authors aim to build understanding of "Dreamers" through these books although there are limitations in how the works of fiction convey the complex and diverse experiences of being undocumented. [Article copies available for a fee from The Transformative Studies Institute. E-mail address: journal@transformativestudies.org Website: http://www.transformativestudies.org (C2020 by The Transformative Studies Institute. All rights reserved.]
\end{abstract}

KEYWORDS: Undocumented Immigrants, Young Adult Literature, Latinx Literature, Dreamers, Nine-Digit Problem, Plyler v. Doe, Education Rights.

As a significant topic within contemporary young adult literature, the portrayal of young people residing in the United States without legal authorization contributes to public dialogue about the legal and socioeconomic situations of undocumented Americans. The publication of books for young readers about undocumented youth rose in the new millennium, particularly the last decade. Elevated awareness coincides with concerns about refugees and asylum-seekers, increased migration needs, and ongoing activism about immigration reform and enforcement

\footnotetext{
${ }^{1}$ Amy Cummins works as Associate Professor and English Education Coordinator in the Department of Literatures and Cultural Studies at the University of Texas Rio Grande Valley. Dr. Cummins teaches courses in children's literature, young adult literature, Mexican American Studies, and English Language Arts pedagogy.
} 
in the United States. Living "sin papeles" (without legal papers) is part of the reality of contemporary American life. This essay evaluates how selected works of fiction targeted to a young adult (teenage) readership portray the situation of living undocumented in the United States. I have chosen to focus on books with Latina or Latino (or Latinx) characters. However, I emphasize that only a small proportion of Latin-origin or Hispanic people in the U.S. are undocumented, and I share concern that over-association of undocumented issues with Latina/o people perpetuates false stereotypes of Latinas/os as newcomers.

Each novel portrays a Latina or Latino teen's struggles. Undocumented status hinders their family and peer relationships, educational goals, finances, work, and futures. In The Secret Side of Empty (2014) by Maria E. Andreu, protagonist Monserrat Thalia, known as M.T., is a high school senior in New Jersey who is hiding the fact that she is undocumented. In Illegal (2011) by Bettina Restrepo, fifteen-year-old Nora has crossed the border with her mother in search of Nora's father, then stayed in Texas. In Sanctuary Somewhere (2019) by Brenna Dimmig, seventeen-year-old Osmel in eastern Washington discovers that he is undocumented during senior year and fears his plans for college and career are impossible.

Through these novels, authors argue implicitly for social change. The first person narrative perspective contributes to a reader's emotional identification with undocumented teen protagonists who face relatable challenges in coming of age, even as their circumstances differ substantially from one another. Situations that can affect any secondaryaged person in the United States are made acute by undocumented legal status. This literature has a significant cultural impact through building empathy and demonstrating resistance to negative public discourse about undocumented residents.

\section{REALITIES OF LIVING UNDOCUMENTED IN THE UNITED STATES}

I use the term "undocumented" in this essay but acknowledge it is an inexact label for the situation of not having United States citizenship, permanent residency, or a current visa. People not authorized for work in the United States still have many papers documenting their lives, such as "birth certificates, baptism records, high school diplomas, family photographs. These just aren't the 'right' documents" (CamineroSantangelo 260). Some activists use terms such as "undocumented citizens" and "noncitizen citizens" to highlight persons as civic 


\section{Amy Cummins}

participants despite marginalization due to lacking authorizations (Hinton 152, 164). The term "1.5 generation" refers to immigrants who relocated to the United States between the ages of 6 and 13, and "undocumented 1.5 generation youth" are those who "migrate at early ages and reside in the United States without legal permission" (Abrego and Gonzales 145). The common term "Dreamer," typically denoting an undocumented person who came to the United States before age 18, but referring to persons of any age, comes from proposed legislation for a federal DREAM Act (Development, Relief, and Education for Alien Minors) that has never been passed.

U.S. President Barack Obama's 2012 executive order Deferred Action for Childhood Arrivals (DACA) allowed approximately 700,000 people to be lawfully present and to work in the United States. Providing a twoyear grace period from deportation, DACA applications were renewable. Many advocates, dissatisfied with "piecemeal reforms," challenge "the 'ideal migrant' discourse" that reinforces a false perception "that most noncitizens are unworthy of regularization and rights" (Dingeman-Cerda, Burciaga, and Martinez 62). DACA is quite limited, providing at most a "liminal legality," a term referring to living on a temporary permit and conveying the sense of "long-term uncertainty" and the extended nature of the gray area between legal categories because the undocumented status returns when "temporary statuses end" due to non-renewal or denial of an application (Menjívar 1001, 1008). Being "DACAlimited" is a term denoting "piecemeal access to opportunities" (Benuto, Casas, Cummings, and Newlands 265). DACA merits continuation and expansion, but current challenges make this unlikely.

In September 2017, the Trump administration rescinded the DACA program, and subsequent legal decisions in February 2018 preserved the program only for "renewal requests from existing DACA recipients," not for any new applicants (Benuto, Casas, Cummings, and Newlands 261). The "legal volleying of the DACA policy" exacerbated anti-immigrant rhetoric and contributed to "a hostile climate that further normalizes hate speech and behavior targeted toward immigrants" (Muñoz, Vigil, Jach, and Rodriguez-Gutierrez 47). On November 12, 2019, the Supreme Court heard oral arguments in this case which is still pending as this article is in press. In 2016, the Supreme Court case United States $v$. Texas dealt with President Obama's 2014 executive order Deferred Action for Parents of Americans and Lawful Permanent Residents (DAPA); the lower court's ruling stood, thus halting that attempt to extend protections from deportation to more people of a wider range of ages and circumstances. 
Efforts to broaden the boundaries of who deserves rights are countermanded by restrictive actions curtailing rights. The "dominant discourse in the United States tends to construct only citizens as having rights" (Caminero-Santangelo 222). Politicians voted down each version of a federal DREAM Act (Development, Relief, and Education for Alien Minors), first submitted in 2001. The Fourteenth Amendment to the United States Constitution, stating that persons born in the United States have birthright citizenship regardless of parentage, has been challenged and undermined. Birth certificates for persons born in Texas have been denied on the basis of types of paperwork presented by undocumented parents. A prominent viewpoint is that the United States should end all immigration, even legal immigration, for fiscal and cultural reasons (Buchanan). In 2019, the U.S. presidential administration placed new restrictions on the asylum system, and the government went into a partial shutdown for 35 days due largely to the issue of funding for a physical border wall between Mexico and the United States.

Advocacy for DREAM legislation often builds on the arguments of Plyer v. Doe, the Supreme Court decision in 1982 that affirmed the K-12 education rights of undocumented students in the United States. The Plyler ruling established that free, public education must be available regardless of citizenship status. The 2012 announcement of the DACA program on the thirtieth anniversary of the court decision demonstrated the duty to undocumented youth growing into adulthood. Threats to the rights guaranteed by Plyler v. Doe lead to cases such as Murillo $v$. Musegades in El Paso, Texas, which was resolved by stopping immigration officers from searching high school students "on mere suspicion of immigration compliance and Mexican appearance" (Olivas 128 , n. 85). Immigration officials should accept the "oasis nature" of a school and its students, regardless of immigration status (Olivas 51). Despite assertions to families about safety on school grounds, parents have legitimate concerns for their children. While Plyler v. Doe guarantees K-12 public education, "a child cannot fully enjoy such right unless his parent feels secure in sending him to school" (López and López 155). Although an educated populace is a public good, educational rights for undocumented youth and teens are not secure.

Most undocumented persons understand their legal status from a young age, but it may be only during adolescence that the "mounting exclusions" bring a full comprehension of the ramifications of the situation (Gonzales 96). Adolescence is said to bring "the transition to illegality" because undocumented young adults are excluded from rites of passage such as driving, voting, and activities requiring authorized 


\section{Amy Cummins}

status (Gonzales 92). While undocumented legal status does not define a person, it carries severe consequences. Many students, even those with strong academic records, become "early exiters" (Gonzales 120). They "lower their aspirations" and may not finish high school when realizing that they cannot have legal employment in the United States or achieve their potential (Abrego, "I Can't" 225). Nevertheless, the nonpartisan Migration Policy Institute estimates in 2019 that "approximately 98,000 unauthorized immigrants graduate from U.S. high schools every year" (Zong and Batalova), more than a 2010 estimate of 65,000 annual graduates (Abrego and Gonzales 145).

Undocumented students and their families get deterred from postsecondary education. To enable a transition to college, mentors, allies, or sponsors are crucial. "Undocumented students who make it to college remain the exception" and have been able to "defy long odds" (Hinton 153). One parent of a Dreamer says: "We had no idea that our daughter qualified for financial aid or that she could even go to college. When you hear so many negative things about being here without documents, you slowly lose hope in things like that" (Ramirez 49). Policies vary and change for in-state resident tuition rates for public colleges in the United States. Eighteen states currently allow undocumented persons access to in-state tuition rates at public higher education institutions or allow applications for state financial assistance, yet state legislatures regularly consider bills that would remove the in-state resident eligibility. Both undocumented persons and "DACAmented" persons (in the Deferred Action for Childhood Arrivals program) are ineligible to receive federal financial aid. Most undocumented persons do not apply to college because tuition is financially unaffordable, even if they know they might be eligible to attend. The states of Alabama and South Carolina prohibit undocumented students from enrolling at any college, while Georgia prohibits undocumented students from attending its more selective public colleges.

When education researchers interviewed undocumented students in high school and college, they found that the undocumented students displayed "strong psychosocial orientation toward schooling," performing academically at superior levels, including earning high grade point averages, Advanced Placement enrollments, and awards (Pérez 64). Moreover, "the survey data underscore the high rates of extracurricular participation among undocumented Latino students," peaking in high school, in addition to exemplary civic engagement (Pérez 65). Likewise, sociological research at a Texas border university found that undocumented students were particularly strong students and active on 
campus, as if compensating for being "socially ascribed by pejorative labels" (Ramirez 50). Scholar Christian Ramirez found that through a focus on maintaining high grade point averages and being involved in campus organizations and university governance, the undocumented students "construct their identities in contrast to negative ascriptions" and present themselves "as model citizens" of the campus (50). Undocumented college students are often among the best by academic measures. These learners show remarkable strength under adverse circumstances, yet it remains important not to "tokenize" outstanding undocumented college students "for their resilience and success in education" (Muñoz, Vigil, Jach, and Rodriguez-Gutierrez 48).

A study of undocumented community college graduates in Arizona recorded feelings of vulnerability and the resilience students must develop. One young man explained his self-conscious nervousness: "When you don't have documents, even the guards in the mall make you nervous. That is, you think ... everybody is looking at you. You don't want to argue about things, you don't want to be noticed" (Castro-Salazar and Bagley 28). Before ultimately obtaining a residency permit, "I felt that I just had a big thing on my head that said 'Immigrant"' (CastroSalazar and Bagley 28). The daily concern about vulnerability to detention and deportation can result in "fear, depression, and anxiety" (Pérez 9). In mixed-status family situations, immigration policies affect citizens who are cognizant that their loved ones face inequities and "blocked access to resources" (Abrego, "Relational" 664).

Occupational options are severely limited for undocumented workers. The limited range of work falls in "unstable, legally risky, dangerous jobs" in the informal economy (Gonzales 120). Exploitation of workers is endemic, including through wage theft, "the denial of wages earned to undocumented workers" (Chávez, Lavariega Monforti, and Michelson 71). Undocumented workers who want their status regularized aspire to move beyond "dead-end jobs" (Chávez, Lavariega Monforti, and Michelson 88). Pathways to legal status can help "to lift these young people out of poverty, integrate them into adult society, and give them opportunities to compete for financial aid or work" (Abrego and Gonzales 153).

Interpersonal relationships are fraught with risk. A major study of Dreamers born in Mexico and raised in the United States was conducted by political scientists immediately after the DACA announcement in June 2012. They found that "intimate and personal relationships" posed an area of great difficulty for people with undocumented standing because the imbalance of status creates "suspicion and distrust" due to 


\section{Amy Cummins}

"the sense of vulnerability about their undocumented status, and having it revealed" (Chávez, Lavariega Monforti, and Michelson 65-66). Fortytwo of the 101 respondents in this study reported "stories of having their immigration status shared without their consent" (71). Exposure can shatter lives and separate families. Some undocumented Americans may operate from the marginalized position "as a source of political activism, while others are nearly immobilized by fear" (66). These conditions are part of the cultural context in which literature gets written, published, and read.

\section{STUDYING YA FICTION ABOUT LIVING UNDOCUMENTED}

Literature portraying undocumented Americans has an important literary and social function to raise awareness and contribute to conversation about a part of many people's daily lives. People with many different backgrounds can be undocumented or have a family with members in different legal statuses. Being undocumented includes families staying after an expired work visa and being unable to get green cards (de la Cruz 49). Multiple authors for teen readers, such as Malín Alegría, Julia Alvarez, Alexandra Diaz, Marie Marquardt, and Sonia Nazario, have written effective books about undocumented and refugee Latinx residents.

Most contemporary authors for young readers empathetically incline toward undocumented persons. The undocumented teen protagonists are somewhat idealized in order to be presented as deserving and meritorious. While novels released for teen readership do not show deliberately negative portrayals of immigrant youth, well-intentioned books may still sensationalize border-crossing, borrow tropes from the suspense and thriller genres, and perpetuate a stereotype of the borderlands as a war zone (e.g., Schafer). The accepting and humanitarian attitude in youth fiction contrasts to anti-immigration viewpoints expressed across other platforms and media. Within a sociopolitical context that often demonizes undocumented persons and families, it is urgent for teen readers to have access to culturally specific narratives that portray aspects of living undocumented and foster understanding. Undocumented persons deserve to see themselves represented more accurately, and diverse stories need to be told.

Some research examines the topic of immigration in young adult literature, yet much more attention to this subject is needed. Scholarship identifies migration themes in books for young readers, globally and for the United States (Maguire and Rodgers; Brown; Lowery). Significant 
patterns have been identified in fiction for teens about the Mexico-United States border and alternative migration (Cummins). Educators have looked at how young adult authors depict immigrant subjects and portray refugee issues (Liang, Brendler, and Galda). Latinx immigrant narratives should be used in school curricula "in a manner that is reflective of local immigrant/ transnational/ transborder communities" (Sánchez and Landa 72), but students should not be expected to talk about their family experiences.

The novels analyzed in this article are all debut young adult novels. One novel has a partly autobiographical basis. Maria E. Andreu, born in Spain, lived for two years in Argentina before coming to the United States at age eight. Although she was undocumented, she had entered the United States before 1982, so the Immigration Reform and Control Act of 1986 during the Reagan administration enabled Andreu to get "on a path to eventual citizenship" (331). Her character M.T. (Monserrat Thalia) in The Secret Side of Empty was brought from her birth country Argentina to New Jersey as an infant. Andreu emphasizes that writing this book "began as a memoir," but it is not a memoir or autobiography (Camacho 31). She did have a similar nickname of M.E. Setting the novel in 2012, Andreu changes events to craft an engaging work of fiction. In published interviews and the "Author's Note" at the end of The Secret Side of Empty, Andreu describes her severe depression and risk of suicide caused by living undocumented. She tells readers about resources; many undocumented teens research online about their situations, attempting to find answers for insurmountable problems.

The other two novels have a foundation not in personally lived experience but in learning from other people. Bettina Restrepo refers on her acknowledgements page for Illegal to being inspired by the stories and situations of people she worked with at Fiesta Mart in Houston. Restrepo identifies as Colombian German American and as a Latina. Emerging author Brenna Dimmig, a teacher of English to Speakers of Other Languages, does not describe her background and is probably White. The "About the Author" paragraph at the end of Sanctuary Somewhere states that Dimmig "lived for several years in the Pacific Northwest as a Jesuit Volunteer," through which she learned about the application processes for DACA and U.S. citizenship, and that "she is passionate to share the stories of the families she came to consider her familia" (n.p.).

The far-ranging geographies in the novels function as a reminder of how undocumented people contribute to life in all states of the union. Andreu's protagonist, M.T., who lives in New Jersey, has no memory of 


\section{Amy Cummins}

her birth country, for she was an infant when her parents brought her to the United States. Restrepo's protagonist, Nora, is a newcomer immigrant to Texas at age fourteen, and she turns fifteen in the course of the book. Dimming's protagonist, Osmel Muñoz, traveled with his expectant mother to the state of Washington when he was five, after his father died.

\section{THE AUTHORS' CHOICES IN NARRATIVE PERSPECTIVE}

While all three novels are told in a first person narrative perspective intended to engage the reader in the emotions and experiences of the undocumented teen, Dimmig's book is a verse novel with one main and one secondary narrator, both in the first person voice. First person voice is the typical choice for contemporary young adult novels because it most immediately connects the reader to the narrator. While it is valuable to have literature featuring characters with whom readers "may develop empathy, and with whom they may form a bond," readers also benefit when they "meet characters they may be indifferent or resistant to" (Rodríguez 78). The audiences for these books include people who do not personally know what it is like to live undocumented as well as people who know from experience. Readership should encompass people for whom the situations are familiar, but there are ways in which the novels do not reflect likely occurrences in the real world. Readers who know undocumented persons or who have gone through the situation will be aware of the limitations of fictional representations.

Andreu's The Secret Side of Empty is most effective in its use of first person narrative voice. M.T.'s voice narrating the novel is forthright, sometimes funny, but often despairing. M.T. has reached a crucial turning point when she cannot continue on to college like her friends are doing. Becoming alienated from her peer group of academically talented senior girls, M.T. cannot plan to attend the trip to England with the National Honor Society. She reflects, "I've missed other trips before so I don't know why this one feels like a bigger deal. I guess it's like the beginning of the end. Of how things will always be from now on" (119). She sabotages her relationship with her first boyfriend, Nate, because she senses "that boys like him don't mingle their futures with futures like mine" (165). M.T. keeps her legal status strictly confidential. When her closest friend, Chelsea, keeps pushing her to get a driver's license and apply to college, M.T. cannot explain her reasons for exclusion from these major rites of passage. As she contemplates how her life is so limited, M.T. shares how she resents her mother and father: "I take a moment to throw little hate daggers in the general direction of my 
parents. For the thousandth time" (83). Despair and absences bring down M.T.'s academic position from being a top student and the Vice-President of the National Honor Society to being a marginal student removed from NHS membership and contemplating death. M.T. muses:

Already I've started to feel the utter pointlessness of continuing to try in school when there is no hope of any more school in my future ... What will all these books and theories and equations matter when I am scrubbing toilets or when I am deported to Argentina and learning a whole new way of doing things from scratch in a country I've never been? (171)

The unique voice of Andreu's novel connects readers with the suffering and harsh reality of an undocumented senior in high school.

Bettina Restrepo also aims for a relatable style and protagonist in Illegal, but language issues expose a flaw in the narrative perspective. Nora speaks to her new friend Keisha with lines such as "I need to English" (138), "Where live?" (164), and "I no have" (245). As scholaractivist Beverly Slapin explains, Restrepo presents Nora's narration and dialogue "in faultless grammatical English" when Nora is communicating to readers or to characters speaking Spanish, but when communicating with English speakers, Nora speaks in a way that "doesn't reflect the actual syntax and rhythms in Spanish that one would expect to find in someone who is struggling with English." Slapin also points out Spanish mistranslations that are among the logical inconsistencies weakening the novel.

Undocumented characters' use of the term "illegal" is a questionable aspect of narrative perspective. It is an issue both of impact and accuracy. In colloquial usage, some undocumented people use the word "illegal," but as if it is in quotation marks. For an author to use the term in a way that reinforces its power arguably undermines the impact of fiction trying to empathize with undocumented persons. Restrepo titles her book Illegal for rhetorical purposes but does not succeed in destigmatizing the term; however, Restrepo boldly transgresses norms by making readers sympathize with a teen conducting unauthorized migration with a measure of choice rather than being taken or sent as a child. Slapin disagrees with Restrepo's choice to have characters refer to themselves as "illegals" because "people who cross without documents do not refer to themselves as 'illegal.' They use the term 'indocumentado' (undocumented) or 'sin papeles' (without papers)." By contrast, Dimmig does not have undocumented characters in Sanctuary Somewhere refer to 


\section{Amy Cummins}

themselves as "illegal," instead using "Dreamer" and "undocumented" throughout the book. This difference between books published in 2011 and 2019 also reflects awareness that the label "illegal" is increasingly unacceptable.

Andreu's M.T. uses the term "illegal" multiple times with an awareness of its socially assigned meanings. She has often wanted to tell Chelsea the truth about herself: "But I can't get over the thought that she would pull back in disgust that she's been having a sneaky little illegal in her life all this time. That somehow I've infiltrated her pure, perfect, charmed life and made it dirty" (91). This passage during M.T.'s downward spiral of despair shows how she has internalized the hateful discourse that regards undocumented persons as a contaminant, as garbage, and as deceptive. M.T. tries to defuse the word of its power when she reveals her undocumented status to class at school as she presents a speech titled "Seventeen Ways to Say Illegal" (299), with "one phrase for every year I've lived here as an illegal immigrant" (300). Finally, Andreu's "Author's Note" opens with a sentence that uses quotation marks to direct attention to the word: "I was 'illegal' like M.T. once" (331). The authorial choice to have undocumented people referring to themselves as "illegal" still troubles readers by reifying the label.

Sanctuary Somewhere, which details Osmel's struggles in senior year to grasp how his legal status affects his hopes for college and career, is the first YA verse novel on the undocumented experience. The dominant feature of verse novels is "character voice in fragments or distinct entries" using free verse without standard rhyme or rhythm (Cadden 134). Plot is created by "the accretion of entries" and structural features such as, for Dimmig, chapter titles and section breaks within the chapterpoems. Enjambment and caesura help readers of verse novels to "manage pace" by communicating that the entries should be read "slowly and emphatically" (Cadden 134-135). White space on the page allows the reader "to speculate about things that are left unsaid" (Cadden 135). Dimmig uses a lot of white space, printing approximately fifty words on a typical page. The book has a total of 43 chapter-poems telling the story in a linear chronology.

Dimmig conveys Osmel's sensation of living in "two worlds" (151) because his unauthorized legal status affects everything. Osmel can get through the day by keeping busy, but at night, "Fear creeps in," and he feels that 
One thousand swirling

black holes are ready

to suck me in and erase

me from the world I know. (151)

Trepidation causes Osmel to "question / all the goals I work / toward during the day" (152). Before talking with his friends about his undocumented status, Osmel wonders several times,

How many of the

people I know here

are Dreamers

like me? (79)

Osmel learns that several of his friends are undocumented, including Maribel, the senior class valedictorian who has been accepted to Yale University (181). They support and encourage one another. Dimmig varies Osmel's first person voice when five of the chapter-poems in Dimmig's Sanctuary Somewhere are narrated in the voice of Leslie, his twelve-year-old sister. Leslie shows love for her brother, who wrestles with envying her for having been born into citizenship. Leslie's voice helps Sanctuary Somewhere convey the experience of growing up in a mixed-status family.

\section{FAMILY SITUATIONS AND THE NINE-DIGIT PROBLEM}

Andreu and Restrepo show mother-daughter teams struggling together against oppressive conditions, and Dimmig portrays a mother-led family with a son and daughter. In Illegal, the father is missing, later known to be deceased, while in The Secret Side of Empty, the father is abusive to M.T., who ultimately leaves her family. Osmel in Sanctuary Somewhere lives with his mother because his father died in Michoacán: "My father is a symbol / of a life I don't / remember" (80). The young adults have to grow up fast and take on substantial responsibility. In both The Secret Side of Empty and Sanctuary Somewhere, the undocumented protagonist also has a younger sibling who was born an American citizen.

Imperatives to reunite her family and gain an education animate Nora's struggle in Illegal. Nora and her mother, Aurora, wait three years in the shrinking town of Cedula in Mexico while Nora's father, Arturo, works in Houston to earn money to send back to support his mother, wife, and daughter. When letters and funds stop coming, Nora and Aurora do an 


\section{Amy Cummins}

irregular border crossing to search for him. While Nora's and her mother's crossing scenario and financial issues are implausible and too easy, the book is told as an adventure or suspense novel. As she leaves Cedula, Nora vows, "This would be the plan: find Papa, get some education, and come back to fix Cedula" (33). Her town's sole school had closed years ago due to impoverishment, "killing my hopes that an education might be a way of fixing everything" (2). Nora imagines making her father proud because "I could put my education to work and save our farm. I could even open a store and sell things from Cedula" (184). She does not stop fantasizing about saving her village, but there is no indication that any of those hopes can come to fruition; she will find new dreams. The mixed impression Restrepo gives of Mexico is as precious yet negative, beautiful yet disappearing, a home and yet no longer home. Although Nora and Aurora do not enter the U.S. with the intention to remain, they stay because the family farm has been lost due to unpaid taxes and because there seems to be nothing to return to. After Nora learns that her father died in a construction accident, she grieves, "We don't even count as people here" (226). Aurora tries to comfort her daughter, "We can start over. We may not matter to America, but we are important to each other" (229). Such passages serve as pleas to the reader that undocumented immigrants matter and deserve respect. Scholar Cristina Rhodes interprets Nora's choices as empowerment through "taking control" of her life by protecting her mother, migrating, and "refusing to be victimized" (23).

M.T.'s father Jorge in The Secret Side of Empty fantasizes about returning to his home country of Argentina. The three of them moved to New Jersey when M.T. was a baby, and her father was 22 years old. Now 39, Jorge has lost his dream and seems stuck in the U.S. because a friend lost the money he had sent back to invest in a business. Anger has led Jorge to depression and violence, and he abuses his wife and daughter verbally and physically. Jorge says M.T. has no need for a computer: "You can't get a real job here. You can't go to college. Stop fooling yourself" (Andreu 56). They are a mixed-status family because José was born in New Jersey. Living in constant fear of deportation caused the family members to lead limited lives. Even though M.T. asks her mother to go with her to a shelter, her mother fears, "You know what would happen if I called the police. They'd deport him. They might deport us all. I could never do that to José and you" (111). M.T. contemplates her options, but they all involve risks of exposure and family separation (185). 
The Secret Side of Empty underscores the educational challenges that undocumented persons face. Although all people have a legal right to a public education from kindergarten to twelfth grade, achieving this is difficult. While people can be enrolled in public schools without a social security number, many parents and educators are not aware of these rights, which are unstable in practice. In the novel, M.T.'s parents do not trust the public school system nor seem to have heard of the law. Her father worries that in "government schools," officials will "check your immigration status" (25). M.T. attends a private, Catholic school. Her mother even consults an immigration attorney, who says her case does not have hope but does not give any further suggestions or information (27). Andreu, who entered school before the Plyler v. Doe decision, does not convey any reference to the rights it established.

The novels provide varying representations of discovering and understanding the significance of one's undocumented legal status. In The Secret Side of Empty, M.T. has known since before kindergarten when she heard her parents disagreeing about her schooling. In Illegal, Nora knows her position because she and her mother travel across the border to search for Nora's father. In Sanctuary Somewhere, Osmel finds out at the age of seventeen, and he fears his plan to become a meteorologist cannot be pursued.

Osmel's belated discovery that he lacks legal authorization during his senior year of high school is an unrealistic aspect of Sanctuary Somewhere. Osmel's mother has refused to tell him, but this delay and secrecy are unlikely in real life. Osmel is one of the men of the family, along with his uncle Jorge, who lives next door. Osmel would already have tried to get a driver's license and employment somewhere in addition to the orchard where his family works picking fruit. Osmel thus would have learned his legal status before Tía Alejandra, called Tía Alex, blurts it to him at a cookout celebrating Leslie's $12^{\text {th }}$ birthday (27). Although it is possible Osmel wanted to ignore the signs, as he reflects, "I thought our whole / family had become / citizens years ago" (29), later incidents do not suggest he was hiding from the truth.

Further, Osmel's Tía Alex, a 25-year-old law student in the DACA program herself, would probably not have waited two weeks to respond to Osmel's text about DACA (53); she would have told Osmel more about the program, not just referred him to a school social worker; and Tía Alex - who recently marched among hundreds of Dreamers at a rally in Seattle (20) - would have known DACA was in jeopardy and no longer taking new applications. Osmel only gets that information after asking the social worker, Guadalupe (Lupe) Soledad, for support in 


\section{Amy Cummins}

achieving his college goal. Further, his mother's calm seems unlikely, such as when she tells Osmel, "You worry so much. / Try not to live in such fear, mijo" (161). Her confident statement that "We are here. We stay here" (161) is a deliberate refusal to be aware of their reality but also functions as attempted reassurance to Osmel — and to the reader, whom Dimmig wants to persuade that Dreamers deserve rights. Although such issues in the novel appear improbable, it is possible they occur sometimes.

The special circumstances that accompany being undocumented are embedded within situations many teens know. Elements of the protagonists' experiences-family, school, work, friendship, rites of passage - are the common currency of United States teen life, even as their situation of lacking authorization complicates everything. Some Dreamers, as undocumented persons striving to remain legally in the U.S., refer colloquially to this situation as having a nine-digit problem. Without a Social Security number (SSN), Dreamers "lack the nine digits that would allow them to fully use their talents in the workplace and to participate in our democratic institutions" (Chavez, LaVariega Monforti, and Michelson 133). The SSN differs from an Individual Tax Identification Number (ITIN), also nine digits, issued by the IRS for noncitizens to pay taxes; the ITIN does not provide legal status or work authorization. DACA recipients received a Social Security number and temporary legal status, though not a path to citizenship.

The novels represent the nine-digit problem of lacking the SSN. In The Secret Side of Empty, M.T. explains for the reader: "The trouble with having parents with no papers: they can't get very good jobs. You need a Social Security number for everything from garbage man to clerk at Walmart. So being an office dude with health insurance and paid vacation time is definitely out" (Andreu 46). M.T. highlights the centrality of that nine-digit number as constraining possibilities, especially financial and occupational.

A chapter-poem in Sanctuary Somewhere is titled "000-00-0000" (157). Osmel is filling out his college application, and when he asks his mother about his social security number, she claims not to know what he means. Tía Alex tells him to put zeros on the SSN line of his college application. Dimmig ends the chapter with Osmel's hope that "someday" he will have a SSN and that he will "remember it by heart" (158). Osmel voices his ardent wish to be a citizen and his frustration at having his aspirations shattered by the recent discovery of his legal status. While his hope may seem unattainable due to politically powerful people in opposition to comprehensive immigration reform, it reflects the author's 
rhetorical aims to persuade people of the need for a federal DREAM act. Dimmig presents a lyrical vision of a future in which change is possible.

\section{DISCLOSURES OF UNDOCUMENTED STATUS}

Disclosure moments in the novels function as a narrative device moving the plot, but they also convey a stance that undocumented persons should be able to be public and not hide the legal status. Whether and whom to tell about being undocumented will differ due to circumstances. When the issue of self-disclosure is raised in these narratives, some moments are presented too idealistically or favorably as part of identity development by the fictional characters. While authors wish to normalize the moments, the marginalization and risks of being undocumented are so substantial that the serious consequences of disclosure must not be understated. For many Dreamers, "family fears" cause them to rely on "secrecy over disclosure" (Gonzales 221), and disclosure requires a high level of trust.

The Secret Side of Empty contains multiple moments of disclosure, the first by M.T.'s mother. After M.T.'s father Jorge loses his income, her mother defies her husband by getting a job outside the home. She is determined to help M.T. finish school and to get her son into the Catholic kindergarten for the next year. With M.T. as the translator or language broker, her mother comes to speak with the principal, Sister Mary Augustus, after M.T.'s tuition bill is overdue. She says point-blank to the principal that the bill cannot be paid because "we're illegals and we can't get very good jobs" (143). M.T. does not want to translate this, but her mother insists (143). This revelation leads to a positive development of her mother's getting a job and M.T.'s staying in school to finish her senior year and graduate.

Three other main instances where M.T.'s undocumented status is revealed occur when M.T. tells Child Protective Services, then her friend Chelsea, and finally her English class. Because M.T.'s erratic behavior has caused her friends to worry she is in imminent danger of suicide $(213,258)$, they notify authorities, and a police officer comes to M.T.'s home to determine whether she is at risk of harming herself. As M.T. walks outside, she tries "to look at everything, wondering if it's the last time before they deport me" (268). Taken to a hospital, M.T. talks to nurses and Child Protective Services. When she finally expresses that she is "illegal," she is told that police will not be informed about the fact (275). M.T. shares her feelings: "I feel the fear washing out of me, leaving me more tired than I've felt in a long time, but a little exhilarated, 


\section{Amy Cummins}

too" (276). The emotion hits hard when reading M.T.'s thoughts: "I've imagined-dreaded - this moment a thousand times, but I've never thought it would be like this, with her [a C.P.S. official] saying that my immigration status doesn't matter to her" (276). The relief is short lived after M.T. returns home to be threatened by her father for putting the whole family at risk of deportation. But M.T. finds sympathy and help for some of her problems, rather than the catastrophe she feared. The cumulative effects of disclosure in Andreu's novel suggest that the result of one's status being known is not as inevitably negative as M.T. was raised to believe. Not intending to diminish the terrible challenge of lacking authorization and being vulnerable, Andreu shows life is not hopeless.

A parallel moment of vulnerability to exposure is seen in Sanctuary Somewhere. In the chapter "The Breakdown," Leslie calls 9-1-1 for help when her mother falls and passes out at the grocery store (136). Osmel is angry at his sister because he fears that the police will come, but the responders with the ambulance ask only for her name and address. Osmel remainsworried that the responders know where they live, "imagining ICE / agents circling / our house as we sleep" (141). This chapter demonstrates the way that undocumented persons know status revelation can lead to family separation although police are different from Border Patrol and ICE. Near the start of the novel, Osmel's Tía Alex discusses being open about her status and participating in public protest. This conversation causes her brother Jorge to have to hold back his anger and worry. Signaling how Jorge is mindful of his responsibilities, "Tío Jorge sighs / as he picks up his son" and warns Alex, "don't cause any problems / for yourself / or the family" (20-21). Osmel himself delays for months before telling his closest friends about his undocumented status, several of whom are also undocumented and exchange this information along with reassurances, providing validation and support for one another.

Restrepo presents Nora's primary disclosure moment as private and consecrated by her relationship with God. After Nora goes to confession and prays at a Catholic Church, she meets with the priest, Father Michael. Nora tells him, "I'm not legal. I don't have any papers," and Father Michael replies, "God doesn't care about your status. He wants you to have faith" (241). Nora and her grandmother immediately walk to the school to register her and are successful, with the help of Nora's friend Keisha and her mother who works there. Through the implication of divine intervention, Restrepo, like Andreu, erases the fact that a free public secondary education is supposed to be a guaranteed right. 


\section{THE SIGNIFICANCE OF ENDINGS}

When the novels end, M.T., Nora, and Osmel are still undocumented and in the United States. This conclusion symbolically represents how Dreamers are here to stay. There are no simple solutions but sometimes temporary respites, as things remain tentative and unresolved for undocumented young adults. But in each case, allies help with obtaining educational opportunity, a significant issue in the conclusions of all three books, with two protagonists going to college, and one in high school.

At the close of Illegal, the mother-daughter relationship has remained resilient, with Nora and Aurora managing the logistical challenges of obtaining enough work, money, and safety to survive. Reuniting the remnants of the family, friends had smuggled Nora's grandmother to Houston. The people who provided them jobs in the underground economy become part of a family rebuilt by circumstances. In an epilogue set "one year later," Nora admits, "I spend less of my time thinking about Cedula, and more on my homework" (249). Nora continues to attend high school, where her African American friend Keisha and her mother helped her to enroll. In the final pages, Nora is having a "sweet sixteen" birthday party, surrounded by the whole family as well as Keisha, and she seems happy.

M.T. in The Secret Side of Empty begins a new stage of her life once she turns eighteen. She cannot fix her father's problems, and "nothing makes the hitting stop when he decides he's going to hit" (Andreu 308). M.T. flees the apartment and calls the police from a neighbor's telephone. She moves in with her wealthy, White best friend Chelsea, who has told M.T. that her legal status would not change their friendship. Chelsea and her mother become M.T.'s allies and provide food, shelter, and opportunity. In the last chapters, Chelsea's mother has helped M.T. get into an unnamed, private college in Connecticut. The access held by people with power and secure legal status provides resources crucial to M.T.'s advancement. Although the novel presents an unrealistic level of assistance and glosses over logistics of financing this costly enterprise, the message of hopefulness is an element of Andreu's intention for her novel.

In the final chapter, M.T., Chelsea, and her mother listen to President Obama's speech about the executive decision DACA in June 2012. As they discuss the significance, M.T. reflects how it could help her although not her mother. M.T. is grateful her brother, José, already has citizenship. This scene reflects the widespread joy experienced when DACA was first announced, and it gives a snapshot from the brief era 


\section{Amy Cummins}

until 2017 when the program was first stopped by the Trump administration. While a character in M.T.'s situation might or might not have been able to get approved for DACA status and for renewals, by ending the novel with the DACA announcement, Andreu shows that positive change can happen. Andreu shared online via her blog that she had wanted to write that her character could gain amnesty, like Andreu had received, so that M.T. could stay "and get on a path to citizenship," but the author gave an ending "to more authentically portray the times in which she's living" (Andreu, "Author's Blog").

As Sanctuary Somewhere ends, Osmel is working toward his goal to become a meteorologist. Dimmig depicts a plausible situation for a young man in his situation although not discussing financial details of Osmel's college attendance. The chapter on "Possible Futures" describes how Lupe's counseling supported Osmel and four friends, also undocumented, in getting college admission. Osmel describes the group's successes before mentioning that he did not get accepted to attend the University of Washington in Seattle, which offers the courses to become a meteorologist. But he was accepted at Big Bend Community College in Moses Lake. Osmel states that he can enroll in science classes there and live at home while working at the orchard "for another two / seasons" (177) so that he can reapply to U.W. the following year, with Lupe as his ally. The achievement of a milestone, Osmel's high school graduation, is celebrated in the next chapters, "Graduation Day" and "Graduation Party." The visual spacing within the verse novel helps a reader to pause and savor the moment, a valuable reminder of a rite of passage many undocumented young adults do not get to enjoy. Osmel thinks, "I have a future / that is better / than okay" (182).

Narrated by Leslie, the final chapter, "Las Cherries," shows respect for Osmel. Leslie voices how she knows no one else "as brave / as Osmel" (190). The emphasis on bravery is particularly noteworthy in light of how Osmel has felt fear due to discovering his undocumented legal status. Leslie praises how "Being undocumented / does not hold / him back" (190). The final words of the book express her admiring view of her brother: "College man. / Future weatherman. / My brother, Osmel" (190). A reader senses the confidence Leslie expresses in her older brother and his perseverance. The emotional conclusion evokes inclusiveness, support, and love-sentiments that Dimmig wants readers to feel and to act upon to bring justice for Dreamers.

These recent novels provide fictional versions of the personal struggles and roadblocks undocumented secondary and post-secondary students face when trying to persist in their educational pathways, work, and 
lives. Because legal status limits so many opportunities, "for most undocumented students, thoughts about their future are automatically connected to their legal status" (Abrego, "I Can't" 224). For people lacking authorization where they reside, the world is constructed with "legal barriers to full participation" (Abrego and Gonzales 155). Unlike the portrayals in the novels, the real situation for most young adults is not as full of hope, allies, or closure. An undocumented young adult may be always on edge and vulnerable due to the marginalized situation. The finality at the end of a fictional narrative is not a likelihood for Dreamers living undocumented in the United States.

\section{CONCLUSION: THE NEED FOR CHANGE}

These authors have made important literary contributions to dialogue about the situation of undocumented Americans and the need for comprehensive immigration reform in the United States. Despite flaws and limitations of the books, the authors Maria E. Andreu, Bettina Restrepo, and Brenna Dimmig humanize, personalize, and individualize an issue often seen statistically and from a distance. Through first-person narrative perspectives, the novels The Secret Side of Empty, Illegal, and Sanctuary Somewhere pull readers into the struggles faced by undocumented teens, two longtime residents and one newcomer. As literature can transport readers into a state of mind to walk in someone else's shoes, the writers of the fictional characters of M.T., Nora, and Osmel expand understanding of living as an undocumented teen in the United States. Although being undocumented does not define a person, daily life and rites of passage are intertwined with the constant problem of being undocumented because legal status imbues every aspect of life with precarity and risk.

The books demonstrate the hardships and unsustainability of living "in the shadows" (Gonzales 62). The authors show the need for undocumented persons to be able to come into the light and to seek opportunity. In each book, families struggle with problems stemming from their legal status. The mothers and young adults obtain employment and learn to navigate the system. The undocumented protagonists get access to education and have significant moments of disclosing legal status. Despite some implausible and idealized representations in the novels, these portrayals suggest the range of experiences that undocumented people may undergo.

The fiction portraying undocumented children and teens particularizes the plight of being undocumented rather than addressing large-scale 


\section{Amy Cummins}

political issues. Partly because of genre and publishing constraints, the books do not provide a sense of the long history of immigrants collectively working for their rights. The YA authors also do not attempt to rebut counter-arguments but rely primarily upon emotional appeal. Fiction writers build sympathetic connections by telling stories about characters affected by the problems, yet more than feelings, actions are needed. Undocumented people deserve respect and solutions rather than being ignored or categorized as a social problem. Dreamers, activists, and scholars have told the stories of undocumented persons seeking to live publicly, not under the radar, and to gain rights. The need for change is past due.

\section{WORKS CITED}

Abrego, Leisy. "'I can't go to college because I don't have papers': Incorporation Patterns of Undocumented Youth." Latino Studies, vol. 4, no. 3, 2006, pp. 212-231. https://doi.org/10.1057/palgrave.lst.8600200

"Relational Legal Consciousness of U.S. Citizenship: Privilege, Responsibility, Guilt, and Love in Latino Mixed-Status Families." Law and Society Review, vol. 53, no. 3, 2019, pp. 641-670. https://doi.org/10.1111/lasr.12414

Abrego, Leisy and Roberto Gonzales. "Blocked Paths, Uncertain Futures: The Postsecondary Education and Labor Market Prospects of Undocumented Latino Youth." Journal of Education for Students Placed at Risk, vol. 15, no. 1-2, 2010, pp. 144-157. https://doi.org/10.1080/10824661003635168

Alegría, Malín. Sofi Mendoza's Guide to Getting Lost in Mexico. Simon and Schuster, 2007.

Alvarez, Julia. Return to Sender. Yearling, 2009.

Andreu, Maria E. The Secret Side of Empty. Running Press Teens, 2014. Author's blog. www.mariaeandreu.com. October 13, 2015.

Benuto, Lorraine, Jena Casas, Caroline Cummings, and Rory Newlands. "Undocumented, to DACAmened, to DACAlimited: Narratives of Latino Students with DACA Status. Hispanic Journal of Behavioral Sciences, vol. 40, no. 3, 2018, pp. 259-278. https://doi.org/10.1177/0739986318776941

Brown, Joanne. Immigration Narratives in Young Adult Literature: Crossing Borders. Scarecrow Press, 2011.

Buchanan, Patrick J. The Death of the West: How Dying Populations and Immigrant Invasions Imperil Our Country and Civilization. St. Martin's Press, 2002. 
Cadden, Mike. "Rhetorical Technique in the Young Adult Verse Novel." Lion and the Unicorn, vol. 42, no. 2, 2018, pp. 129-144. https://doi.org/10.1353/uni.2018.0014

Camacho, Haydee. "From Memoir to Fiction: Maria Andreu Talks about The Secret Side of Empty." Voices of Youth Advocates, vol. 38, no. 2, 2015, p. 31.

Caminero-Santangelo, Marta. Documenting the Undocumented: Latino/a Narratives and Social Justice in the Era of Operation Gatekeeper. University Press of Florida, 2016. https://doi.org/10.5744/florida/9780813062594.001.0001

Castro-Salazar, Ricardo, and Carl Bagley. "'Ni De Aqui Ni from There.' Navigating Between Contexts: Counter-Narratives of Undocumented Mexican Students in the United States." Race, Ethnicity, and Education, vol. 13, no. 1, 2010, pp. 23-40. https://doi.org/10.1080/13613320903549651

Chávez, Maria et al. Living the Dream: New Immigration Policies and the Lives of Undocumented Latino Youth. Paradigm Publishers, 2015. https://doi.org/10.4324/9781315633626

Cummins, Amy. "Border Crossings: Undocumented Migration Between Mexico and the United States in Contemporary Young Adult Literature." Children's Literature in Education, vol. 44, no. 1, 2013, pp. 57-73. https://doi.org/10.1007/s10583-012-9176-1

De la Cruz, Melissa. Something In Between. Harlequin Teen, 2016.

Diaz, Alexandra. The Only Road. Simon and Schuster, 2016.

Diaz, Alexandra. The Crossroads. Simon and Schuster, 2018.

Dimmig, Brenna. Sanctuary Somewhere. Enslow Publishing, 2019.

Dingeman-Cerda, Katie, Edelina Muñoz Burciaga, and Lisa M. Martinez. "Neither Sinners Nor Saints: Complicating the Discourse of Noncitizen Deservingness." Association of Mexican-American Educators Journal, vol. 9, no. 3, 2015, pp. 62-73.

Gonzales, Roberto G. Lives in Limbo: Undocumented and Coming of Age in America. University of California Press, 2016. https://doi.org/10.1111/ciso.12107

Hinton, Kip Austin. "Undocumented Citizens: The Civic Engagement of Activist Immigrants." Education, Citizenship and Social Justice, vol. 10, no. 2, 2015, pp. 152-167. https://doi.org/10.1177/1746197915583933 Lian, Lauren Aimonette, Beth Brendler, and Lee Galda. "The Refugee Experience in Books for Adolescents." Journal of Children's Literature, vol. 35, no. 2, 2009, pp. 59-68. 


\section{Amy Cummins}

López, María Pabó and Gerardo R. López. Persistent Inequality: Contemporary Realities in the Education of Undocumented Latina/o Students. Routledge, 2010. https://doi.org/10.4324/9780203865132

Lowery, Ruth McKoy. Immigrants in Children's Literature. Peter Lang, 2000. Maguire, Nora, and Beth Rodgers, eds. Children's Literature on the Move: Nations, Translations, Migrations. Four Courts Press, 2013. https://doi.org/10.3366/ircl.2014.0139

Marquardt, Marie. Dream Things True. St. Martin's Press, 2015.

Menjívar, Cecilia. "Liminal Legality: Salvadoran and Guatemalan Immigrants' Lives in the United States." American Journal of Sociology, vol. 111, no. 4, 2006, pp. 999-1037. https://doi.org/10.1086/499509

Muñoz, Susana, Darsella Vigil, Elizabeth Jach, and Marisela RodriguezGutierrez. "Unpacking Resilience and Trauma: Examining the 'Trump Effect' in Higher Education for Undocumented Latinx College Students." Association of Mexican American Educators Journal, vol. 12, no. 3, 2018, pp. 33-52. https://doi.org/10.24974/amae.12.3.405

Nazario, Sonia. Enrique's Journey: The True Story of a Boy Determined to Reunite with His Mother, Adapted for Young People. Random House, 2013.

Olivas, Michael. No Undocumented Child Left Behind: Plyler v. Doe and the Education of Undocumented Schoolchildren. NYU Press, 2012. https://doi.org/10.18574/nyu/9780814762448.001.0001

Pérez, William. Americans By Heart: Undocumented Latino Students and the Promise of a Higher Education. Teachers College Press, 2012.

Ramirez, Christian. "Marginalized Within the Borderlands: The Undocumented Citizen Students of the University of Texas Pan American." UTPA M.S. Sociology Thesis. May 2012.

Restrepo, Bettina. Illegal. Katherine Tegan, Harper Collins, 2011.

Rhodes, Cristina. "Female Empowerment and Undocumented Border Crossing in Bettina Restrepo's Illegal." Bookbird, vol. 55, no. 3, 2017, pp. 20-26. https://doi.org/10.1353/bkb.2017.0033

Rodríguez, R. Joseph. Teaching Culturally Sustaining and Inclusive Young Adult Literature: Critical Perspectives and Conversations. Routledge, 2019. https://doi.org/10.4324/9781315098555

Sánchez, Patricia, and Maité Landa. "Cruzando Fronteras: Negotiating the Stories of Latino Immigrant and Transnational Children." Multicultural Literature for Latino Bilingual Children: Their Words, Their Worlds, edited by Ellen Riojas Clark, Belinda Bustos Flores, Howard L. Smith, and Daniel Alejandro González, Rowman and Littlefield, 2016, pp. 69-82. https://doi.org/10.1080/15348431.2016.1231610 
Schafer, Steve. The Border. Sourcebooks, 2017.

Slapin, Beverly. "Illegal by Bettina Restrepo." De Colores: The Raza Experience in Books for Children. Blog. 30 March 2019. www.decoloresreviews.blogspot.com.

Zong, Jie, and Jeanne Batalova. "How Many Unauthorized Immigrants Graduate from U.S. High Schools Annually?" Migration Policy Institute. April 2019. www.migrationpolicy.org/research/unauthorizedimmigrants-graduate-us-high-schools. 